\title{
Correction to: Feedforward discharges couple the singing central pattern generator and ventilation central pattern generator in the cricket abdominal central nervous system
}

\author{
Stefan Schöneich ${ }^{1,2} \cdot$ Berthold Hedwig $^{1}$ (D) \\ Published online: 13 January 2020 \\ (c) The Author(s) 2020

\section{Correction to: \\ Journal of Comparative Physiology A \\ (2019) 205:881-895 \\ https://doi.org/10.1007/s00359-019-01377-7}

The authors listed the following reference:

Burrows M (1996) Breathing. In: Burrows M (ed) The neurobiology of an insect brain, chap 12. Oxford University Press, Oxford, pp 563-596

M. Burrows is the sole author of the book, an editor was not involved. The reference should read:

Burrows M (1996) Chapter 12: Breathing. In: The neurobiology of an insect brain. Oxford University Press, Oxford, pp 563-596

The authors apologise for citing incorrectly.
Open Access This article is licensed under a Creative Commons Attribution 4.0 International License, which permits use, sharing, adaptation, distribution and reproduction in any medium or format, as long as you give appropriate credit to the original author(s) and the source, provide a link to the Creative Commons licence, and indicate if changes were made. The images or other third party material in this article are included in the article's Creative Commons licence, unless indicated otherwise in a credit line to the material. If material is not included in the article's Creative Commons licence and your intended use is not permitted by statutory regulation or exceeds the permitted use, you will need to obtain permission directly from the copyright holder. To view a copy of this licence, visit http://creativecommons.org/licenses/by/4.0/.

Publisher's Note Springer Nature remains neutral with regard to jurisdictional claims in published maps and institutional affiliations.

The original article can be found online at https://doi.org/10.1007/ s00359-019-01377-7.

Berthold Hedwig

bh202@cam.ac.uk

1 Department of Zoology, University of Cambridge, Cambridge, UK

2 Institute of Zoology and Evolutionary Research, Friedrich-Schiller-University Jena, Jena, Germany 